\title{
Single-strand Conformation Polymerase Chain Reaction
}

National Cancer Institute

\section{Source}

National Cancer Institute. Single-strand Conformation Polymerase Chain Reaction. NCI

Thesaurus. Code C130183.

A modified polymerase chain reaction (PCR) technique that uses differences in molecular weights and three-dimensional structures to identify mutations in DNA configurations. 